\title{
ANALISIS REALISASI ANGGARAN UNTUK MENILAI EFEKTIVITAS DAN EFISIENSI KINERJA PEMERINTAH DI DINAS PERTANIAN DAN PETERNAKAN PROVINSI SULAWESI UTARA
}

\author{
Cindy Kareima Waney ${ }^{1}$, David P.E Saerang ${ }^{2}$, Stanley W. Alexander ${ }^{3}$ \\ 1,2,3 Jurusan Akuntansi, Fakultas Ekonomi dan Bisnis, Universitas Sam Ratulangi, Jl. Kampus Bahu, Manado, \\ 95115, Indonesia \\ E-mail : cindywaney2@gmail.com
}

\begin{abstract}
Good governance is an eminent issue in the management of government administration today. The implementation of local government can not be separated from the use and utilization of budget and regional income. And every year it is always the local goverment preparing a budget plan or called regional income and expenditure budgets. The purpose of this study analyzed the budget realization report to assess the effectineness and efficiency od government performance in aggriculture and livestock servive of North Sulawesi Province period 2012-2014. Data analysis method used is data analysis calculation of effectiveness and efficiency. Level or criteria of effectiveness of expenditure budget in agriculture and livestock service of North Sulawesi Province 2012-2014 vary for effevtive use the budget is quite effective in 2012 and 2013-2014 effective budget usage. So overall from 2012-2014, the level of effectiveness of agriculture and livestock expenditure budget of North Sulawesi Province experienced an effective increase. In the implementation of agriculture and livestock expenditure budget of the province of North Sulawesi in 2012-2014, already well processed and very efficient. Implementation of the 2012-2014 budget is categorized as very efficient because the efficiency level below $60 \%$.
\end{abstract}

Keywords : efficiency, effeectiveness, budget

\section{PENDAHULUAN}

Direvisinya UU No. 22 tahun 1999 ke UU No. 32 tahun 2004 tentang Pemerintahan Daerah dan UU No. 25 tahun 1999 ke UU No. 33 tahun 2004 tentang Perimbangan Keuangan antara Pemerintah Pusat dan Daerah merupakan perundang - undangan yang berhubungan dengan kebijakan desentralisasi dan otonomi daerah. Pelaksanaan desentralisasi dan otonomi daerah di Indonesia hingg saat ini dianggap masih belum memberikan hasil yang baik dan menggembirakan dalam persoalan kemajuan tingkat ekonomi, kualitas sumber daya manusia, dan kekayaan sumber alam. Kemampuan pemerintah daerah dalam mengelola keuangan termuat dalam Anggaran Pendapatan dan Belanja Daerah (APBD) yang menggambarkan kemampuan pemerintah daerah dalam membiayai kegiatan pelaksanaan tugas pembangunan, Untuk itu pemerintah daerah dituntut untuk mampu membangun ukuran kinerja yang baik. Ukuran kinerja yang disusun tidak dapat hanya dengan menggunakan suatu ukuran. Perlu ukuran yang berbeda untuk tujuan yang berbeda. Kinerja diukur melalui penggunaan pengukuran kinerja dimana suatu matrik digunakan untuk mengkuantifikasi efisiensi atau efektivitas dari suatu kegiatan (Matthews,2011) Penyusunan anggaran pendapatan dan belanja daerah (APBD), pemerintah daerah telah menerapkan partisipasi setiap satuan kerja dalam penyusunan anggaran masing-masing SKPD memuat Rencana Kerja Anggaran (RKA) yang biasa disebut RKA SKPD . Dalam RKA SKPD, masing-masing SKPD telah memuat indikator kinerja yang akan dicapai untuk setiap program dan kegiatan yang akan 
dilaksanakan. Dalam RKA telah memuat input, output dan outcome dari masing-masing program dan kegiatan, jadi dalam RKA telah memuat sasaran anggaran.

Efisiensi dan Efektivitas dapat melihat sejauh mana suatu keadaan keuangan mempergunakan atau memanfaatkan sumber-sumber daya yang ada secara ekonomis, hemat (efisien) dan dilakukan secara tepat dan memenuhi sasaran (efektif) serta hasil yang dicapai tersebut memiliki rasionalitas terhadap penggunaan sumber-sumber yang ada (produktivitas). Efisiensi (Daya Guna) merupakan perbandingan antara output dengan input (Endah : 2015). Organisasi sektor publik akan dinilai baik jika yang bersangkutan mampu dalam melaksanakan tugas dalam mencapai tujuan yang telah ditetapkan pada standar yang tinggi dan biaya yang rendah. Tuntutan baru untuk organisasi sektor publik yaitu selalu memperhatikan value for money. Karena tujuan yang dikehendaki masyarakat selalu mencakup pertanggungjawaban mengenai pelaksanaan value for money, yaitu dalam pengadaan dan dan alokasi sumber daya dalam arti penggunaannya diminimalkan dan hasil dimaksimalkan (maximizing benefits and minimizing cost), serta (berhasil guna) dalam arti mencapai tujuan dan sasaran (Sumenge : 2013).

\section{TINJAUAN PUSTAKA}

\subsection{Pengertian Akuntansi}

Horgen et al (2012) dalam Pontoh (2013) menyatakan Akuntansi adalah sebuah system informasi yang mengukur aktifitas bisnis, memproses data suatu kejadian ekonomi menjadi laporan, dan mengkomunikasikan hasilnya kepada para pengambil keputusan.

\subsection{Akuntansi Pemerintah}

Akuntansi pemerintah merupakan bagian dari akuntansi sektor publik. Akuntansi pemerintah adalah akuntansi yang bersangkutan dengan bidang keuangan Negara, dari anggaran sampai dengan pelaksanaan dan pelaporannya, termasuk segala pengaruh yang ditimbulkannya (Sujarweni, $2016: 18$ ).

\subsection{Pengertian Keuangan Daerah dan Pengelolaannya}

Pengertian pengelolaan keuangan adalah pelaksaan yang meliputi penyusunan, penetapan, pelaksanaan pengawasan, dan perhitungan anggaran pendapatan dan belanja daerah (Agustina 2013).

\subsection{Dasar Hukum Pengelolaan Keuangan Daerah}

Berdasarkan Undang-undang Dasar 1945 pasal 18 yang menyebutkan bahwa Negara Kesatuan Republik Indonesia dibagi atas daerah-daerah provinsi dan daerah provinsi dibagi atas kebupaten dan kota, yang tiap-tiap provinsi, kabupaten, dan kota ini mempunyai pemerintahan daerah yang diatur dalam undang-undang.

\subsection{Pengertian Anggaran}

Anggaran adalah suatu proses perencanaan kegiatan bisnis masa depan, yang hasilnya didokumentasikan dengan sistem anggaran (Klychova : 2014). Anggaran dapat dianggap sebagai instrumen planing serta controling operasi keuntungan dalam organisasi laba dimana tingkat formalitas budget tergantung kapasitas organisasi.

\subsection{Anggaran Sektor Publik}

Anggaran Sektor Publik adalah perencanaan finansial tentang perkiraan pengeluaran dan penerimaan yang diharapkan akan terjadi di masa mendatang dengan melihat data yang diperoleh dari masa lalu sebagai acuan penetapan anggaran. Dalam organisasi sektor publik, penganggaran merupakan suatu proses politik. Karena pada sektor publik anggaran harus diinformasikan kepada publik untuk di kritik, didiskusikan, dan di beri masukan.

\subsection{Laporan Realisasi Anggaran}

Laporan Realisasi Anggaran (LRA) menyajikan ikhtiar sumber, alokasi, dan pemakaian sumber daya ekonomi yang dikelolah pemerintah pusat/daerah, yang 
menggambarkan perbandingan antara anggaran dan realisasinya dalam satu periode pelaporan.

\subsection{Belanja Daerah}

Belanja daerah meliputi keseluruhan pengeluaran dari rekening kas umum daerah (kasda) yang menyebabkan berkurangnya ekuitas dana lancar, yang menjadi kewajiban daerah dalam satu tahun anggaran yang tidak diperoleh kembali pembayarannya oleh daerah. Belanja daerah adalah keseliruhan pengeluaran dari rekening kas umum daerah (kasda) yang menyebabka berkurangnya ekuitas dana (Mandey: 2015)

\subsection{Efektivitas}

Efektivitas pada dasarnya berhubungan dengan pencapaian tujuan atau target kebijakan (hasil guna). Efektivitas merupakan hubungan antara keluaran dengan tujuan dan sasaran yang harus dicapai. Kegiatan operasional dikatakan efektif apabila proses kegiatan mencapai tujuan dan sasaran akhir kebijakan (spending wisely).

\subsection{Efisiensi}

Mardiasmo (2009) Efisiensi berhubungan erat dengan konsep produktifitas. Pengukuran efisiensi dilakukan dengan membandingkan antara output yang dihasilkan terhadap input yang digunakan (cost of output).

\subsection{Penelitian Terdahulu}

Mewengkang (2010), dengan penelitian berjudul Efisiensi dan Efiktivitas Pengelolaan Keuangan Daerah di Provinsi Sulawesi Utara. Hasil penelitian menunjukan bahwa rasio efisiensi berada pada posisi kurang efisien sedangkan efiktivitas pada posisi sangat efektif. Persamaanya dengan penelitian ini adalah meneliti tentang tingkat efisiensi dan efektivitas dari pengelolaan keuangan daerah, sedangkan perbedaanya terletak pada objek penelitian.

Meninjau hasil penelitian yang dilakukan oleh Devy Oktaviana (2014), penelitian berjudul Analisis Efektivitas dan Efisiensi Pajak Daerah Serta Kontribusinya Terhadap Pendapatan Asli Daerah Di Provinsi Jawa Tengah. Berdasarkan hasil penelitian dapat diketahui bahwa Penerimaan pajak daerah provinsi jawa tengah selama periode 2008-2012 sangat Efektifis dan Efisien. Persamaanya dengan penelitian ini adalah meneliti tentng efektivitas dan efisien dari pada kinerja pemeerintah. Perbedaanya adalah penelitian ini menggunakan Laporan Realisasi Anggaran sebagai dasar perhitungan.

\section{METODOLOGI PENELITIAN}

\subsection{Jenis Penelitian}

Jenis penelitian tentang analisis realisasi anggaran untuk menilai efektivitas dan efisiensi kinerja pemerintah di dinas pertanian dan peternakan provinsi sulawesi utara, menggunakan adalah penelitian deskriptif kualitatif yang mendeskripsikan data apa adanya dan menjelaskan data atau kejadian dengan kalimat penjelasan secara kualitatif.

\subsection{Tempat dan Waktu Penelitian}

Tempat dilakukannya penelitian adalah Dinas Pertanian Dan Peternakan Provinsi Sulawesi Utara yang beralamat di Kalasey Satu, Pineleng, Kabupaten Minahasa, Provinsi Sulawesi Utara, Indonesia. Pengumpulan data penelitian Di Dinas Pertanian Dan Peternakan Provinsi Sulawesi Utara di mulai pada Bulan Oktober 2017.

\subsection{Prosedur Penelitian}

Prosedur penelitian merupakan langkah-langkah atau urutan yang harus dilalui atau dikerjakan dalam suatu penelitian. Maka prosedur penelitian harus dilakukan oleh peneliti sebagai berikut :

1. Melakukan studi kepustakaan (Studi Pendahuluan)

2. Merumuskan Masalah

3. Menentukan Objek Penelitian 
4. Mengumpulkan Data yang berupa Laporan Realisasi Anggaran Dinas Pertanian dan Peternakan provinsi Sulawesi Utara.

5. Mengolah dan Menyajikan Data

6. Menganalisis data dengan cara menghitung efisiensi dan efektivitas pelaksanaan laporan realisasi anggaran di Dinas Pertanian dan Peternakan Provinsi Sulawesi Utara

7. Membuat Kesimpulan dan Saran sehingga dapat menjadi masukan bagi Dinas Pertanian Dan Peternakan Provinsi Sulawesi Utara.

\subsection{Metode Pengumpulan Data}

Data yang digunakan dalam penelitian ini adalah data kualitatif dan kuantitatif. Data kualitatif adalah data yang di sajikan secara deskriptif atau data yang berbentuk uraian, sedangkan data kuantitatif adalah data yang diukur dalam suatu skala numerik atau angka angka. Sumber data yang digunakan dalam penelitian ini adalah data sekunder dimana data diperoleh atau dikumpulkan, yang berupa data dokumentasi dan arsip-arsip resmi. Data ini bersumber dari Dokumen Laporan Realisasi Anggaran Belanja Dinas Pertanian dan Peternakan Provinsi Sulawesi Utara.

\subsection{Metode Analisis Data}

Analisis data yang digunakan adalah secara deskriptif kuantitatif yaitu dengan cara mengumpulkan data, disusun, dienterprestasikan dan analisis sehingga memberikan kesimpulan yang jelas dan objektif terhadap masalah yang ada yaitu mengenai kinerja di Dinas Pertanian Dan Peternakan Sulawesi Utara dengan dilihat dari segi efisisensi dan efektivitas laporan relisasi anggaran.

\subsubsection{Perhitungan Tingkat Efektivitas}

Untuk bisa mengetahui dan mengukur tingkat efektivitas pelaksanaan anggaran belanja Dinas Pertanian Dan Peternakan Provinsi Sulawesi Utara, maka digunakan rumus (Mohamad Mahsun, 2009):

$$
\text { Efektifitas }=\frac{\text { Realisasi Anggaran Belanja }}{\text { Target Anggaran Belanja }} \quad \mathrm{x} \quad 100 \%
$$

\subsubsection{Perhitungan Tingkat Efisiensi}

Pada dasarnya efisiensi menunjukkan pengukuran pencapaian output yang maksimum dengan penggunaan sumber daya dan dana yang serendah-rendahnyanya. Maka digunakan rumus sebagai berikut (Mohamad Mahsun, 2009):

Efisiensi $=\frac{\text { Realisasi Anggaran Belanja }}{\text { Langsung }} \times 100 \%$

\section{HASIL PENELITIAN DAN PEMBAHASAN \\ 4.1 Hasil Penelitian}

\subsubsection{Analisis Tingkat efektivitas Anggaran Belanja}

Tabel dibawah ini merupakan Realisasi anggaran belanja di Dinas Pertanian Dan Peternakan Provinsi Sulawesi Utara. 


\section{Tabel 4.1}

Realisasi Anggaran Belanja Dinas Pertanian dan Peternakan Provinsi SULUT

Tahun 2012-2016

\begin{tabular}{|c|c|c|}
\hline Tahun & Target Anggaran & Realisasi \\
\hline 2012 & 45.037 .669 .000 & 40.504 .706 .231 \\
\hline 2013 & 60.778 .094 .857 & 57.502 .710 .070 \\
\hline 2014 & 57.884 .267 .003 & 54.288 .263 .099 \\
\hline 2015 & 55.340 .211 .020 & 50.125 .264 .660 \\
\hline 2016 & 64.023 .195 .600 & 60.840 .590 .000 \\
\hline
\end{tabular}

\section{Sumber : Dinas Pertanian Dan Peternakan Provinsi Sulawesi Utara}

Belanja dinas pertanian dan peternakan provinsi Sulawesi Utara baik yang sudah ditargetkan dan yang direalisasikan mengalami penurunan ditahun 2012 yaitu target anggaran sebesar Rp. 45.037.669.000 yang direalisasikan sebesar Rp. 40.504.706.231. Kemudian di tahun 2013 mengalami peningkatan yaitu dianggarkan sebesar Rp. 60.778.094.857 dan yang direalisasikan sebesar Rp. 57.502.710.070. Pada tahun 2014 mengalami penurunan yaitu yang dianggarkan sebesar Rp. 57.884.267.003 dan yang direalisasikan sebesar Rp. 54.288.263.099. Kemudian di tahun 2015 terjadi lagi penurunan yaitu yang dianggarkan Rp. 55.340.211.820 dan yang terealisasikan Rp. 52.125.264.660. Setelah 2 tahun berturut-turut menurun di tahun 2016 terjadi peningkatan yaitu yang dianggarkan 62.023.195.600 dan yang direalisasikan 59.840.590.000. Untuk bisa mengetahui tingkat efektivitas, harus menggunakan rumus sebagai berikut :

$$
\text { Efektifitas }=\frac{\text { Realisasi Anggaran Belanja }}{\text { Target Anggaran Belanja }} \quad \text { x } \quad 100 \%
$$

\subsubsection{Analisis Tingkat Efisiensi Anggaran Belanja}

Tabel dibawah ini akan menunjukan jumlah realisasi belanja langsung dan total realisasi belanja Dinas Pertanian dan Peternakan Provinsi Sulawesi Utara

Tabel 4.2

Realisasi Anggaran Belanja Langsung dan Total Realisasi Anggaran Belanja Dinas Pertanian dan Peternakan Provinsi Sulawesi Utara Tahun 2012 - 2016

\begin{tabular}{|c|c|c|}
\hline Tahun & Realisasi Belanja Langsung (Rp) & Realisasi Belanja (Rp) \\
\hline 2012 & 16.279 .499 .584 & 40.504 .706 .231 \\
\hline 2013 & 32.509 .510 .778 & 57.502 .710 .070 \\
\hline 2014 & 24.707 .145 .574 & 54.288 .263 .099 \\
\hline 2015 & 20.430 .286 .330 & 50.125 .264 .660 \\
\hline 2016 & 35.110 .060 .240 & 60.840 .590 .000 \\
\hline
\end{tabular}

Sumber : Laporan Realisasi Anggaran Dinas Pertanian Dan Peternakan Pprovinsi Sulawesi Utara

Dari tabel diatas, akan dihitung tingkat efisiensi anggaran belanja dengan menggunakan rumus sebagai berikut :

Realisasi Anggaran Belanja

Efisiensi $\frac{\text { Langsung }}{\text { Target Anggaran Belanja }} \times 100 \%$

Menurut Keputusan Menteri Dalam Negeri Nomor 690.900-327 Tahun 1996, Mengenai kriteria tingkat efisiensi anggaran belanja adalah sebagai berikut : 
1. Jika hasil perbandingan melebih $100 \%$, maka angggaran belanja TIDAK EFISIEN.

2. Jika hasil pencapaian antara $90 \%$ - 100\%, maka anggaran belanja dikatakan KURANG EFISIEN.

3. Jika hasil pencapaian antara $80 \%$ - 90\%, maka anggaran belanja dikatakan CUKUP EFISIEN.

4. Jika hasil pencapaian antara $60 \%-80 \%$, maka anggaran belanja dikatakan EFISIEN.

5. Jika hasil pencapaian dibawah $60 \%$, maka anggaran belanja dikatakan SANGAT EFISIEN.

\subsection{Pembahasan}

4.2.1 Efektivitas anggaran Belanja Dinas Pertanian Dan Peternakan Provinsi Sulawesi Utara

Berikut disajikan tabel yang menggambarkan tingkat efektivitas anggaran belanja dari tahun 2012 - 2016 pada Dinas Pertanian dan Peternakan Provinsi Sulawesi Utara

Tabel 4.3

Tingkat Efektivitas Pelaksanaan Anggaran Belanja Dinas Pertanian Dan Peternakan Provinsi Sulawesi Utara Tahun 2012 - 2016

\begin{tabular}{|c|c|c|c|c|}
\hline Tahun & Target (Rp) & Realisasi (Rp) & $\begin{array}{c}\text { Tingkat } \\
\text { Efektifitas } \\
(\mathbf{\%})\end{array}$ & Kriteria \\
\hline 2012 & 45.037 .669 .000 & 40.504 .706 .231 & $89.93 \%$ & Cukup Efektif \\
\hline 2013 & 60.778 .094 .857 & 57.502 .710 .070 & $94,61 \%$ & Efektif \\
\hline 2014 & 57.884 .267 .003 & 54.288 .263 .099 & $93,78 \%$ & Efektif \\
\hline 2015 & 55.340 .211 .020 & 50.125 .264 .660 & $90,57 \%$ & Efektif \\
\hline 2016 & 64.023 .195 .600 & 60.840 .590 .000 & $94,98 \%$ & Efektif \\
\hline
\end{tabular}

Sumber : Laporan Realisasi Anggaran Dinas Pertanian Dan Peternakan Provinsi Sulawesi Utara (Data Olahan)

Dari tabel diatas dapat dilihat selama periode anggaran tahun 2012 - 2016, tingkat efektivitas anggaran belanja tidak tetap dari tahun ketahun, dari yang cukup efektif sampai mengalami peningkatan yang efektif. Pada tahun 2012 tingkat efektifitasnya yaitu 89,93\% dikatakan cukup efektif, kemudian di tahun 2013 mengalami peningkatan yang efektif yaitu $94,61 \%$, sampai pada tahun 2014 tingkat efektivitasnya menurun sedikit yaitu 93,78\% begitu juga ditahun 2015 sedikit menurun yaitu 90,57 \% dan ditahun 2016 terjadi sedikit peningkatan menjadi $94,98 \%$ masih tetap efektif.

Jadi secara keseluruan dari tahun 2012 - 2016, tingkat efektivitas anggaran belanja

Dinas Pertanian Dan Peternakan Provinsi Sulawesi Utara mengalami peningkatan yang efektif. Tahun 2012 yang tingkat efektivitasnya berada dalam kategori cukup efektif dan pada tahun 2013 - 2016 tingkat efektivitasnya sudah bisa menunjukan efektif.

\subsubsection{Efisiensi Anggaran Belanja Dinas Pertanian Dan Peternakan Provinsi Sulawesi Utara}

Dibawah ini akan menunjukan tabel tingkat efisiensi anggaran belanja Dinas Pertanian Dan Peternakan Provinsi Sulawesi Utara. 


\section{Tabel 4.4}

Tingkat Efisiensi Pelaksanaan Anggaran Belanja Dinas Pertanian Dan Peternakan Provinsi Sulawesi Utara Tahun 2012 - 2016

\begin{tabular}{|c|c|c|c|c|}
\hline Tahun & $\begin{array}{c}\text { Realisasi Belanja } \\
\text { Langgsung (Rp) }\end{array}$ & $\begin{array}{c}\text { Realisasi } \\
\text { Belanja (Rp) }\end{array}$ & $\begin{array}{c}\text { Tingkat } \\
\text { Efisiensi } \\
(\mathbf{\%})\end{array}$ & Kriteria \\
\hline 2012 & 16.279 .499 .584 & 40.504 .706 .231 & $40,19 \%$ & Sangat Efisien \\
\hline 2013 & 32.509 .510 .778 & 57.502 .710 .070 & $56,53 \%$ & Sangat Efisien \\
\hline 2014 & 24.707 .145 .574 & 54.288 .263 .099 & $45,51 \%$ & Sangat Efisien \\
\hline 2015 & 20.430 .286 .330 & 50.125 .264 .660 & $40,78 \%$ & Sangat Efisien \\
\hline 2016 & 35.110 .060 .240 & 60.840 .590 .000 & $57,70 \%$ & Sangat Efisien \\
\hline
\end{tabular}

Sumber : Laporan Realisasi Anggaran Dinas Pertanian Dan Peternakan Provinsi Sulawesi Utara (Data Olahan)

Tabel diatas menunjukan tingkat efisiensi dari anggaran belanja yang ada di Dinas Pertanian dan Peternakan Provinsi Sulawesi Utara yang tidak tetap dari tahun ke tahun. Pada tahun 2012 tingkat efisiensi yang didapat sebesar 40,19\% dan pada tahun 2013 tingkat efisiensi sebesar 56,53\%. Dari sudut pandang tingkat efisiensi ini dipandang sebagai penurunan tingkat efisiensi tetapi masih termasuk dalam kriteria sangat efisien karena masih dibawah 60\%. Pada tahun 2014 mengalami sedikit peningkatan tingkat efisien sebesar 45,51\% dan pada tahun 2015 terjadi peningkatan kembali sebesar 40,75\% dan ditahun 2016 kembali turun menjadi $57,70 \%$ tapi masih masuk dalam kriteria sangat efisien karena masih dibawah 60\%. Kedepannya pemerintah daerah atau terlebih khusus Dinas Pertanian Dan peternakan Provinsi Sulawesi Utara agar dapat mempertahankan tingkat efisisensi laporan relisasi anggaran dengan meningkatkan terus pengawasan, pelayanan, dan koordinasi pemerintah agar supaya realisasi pendapatan asli daerah lebih maksimal.

\section{KESIMPULAN DAN SARAN \\ 5.1 Kesimpulan}

Berdasarkan dari hasil penelitian dan analisis yang telah dilakukan, maka disimpulkan bahwa :

1. Pengelolaan anggaran belanja di Dinas Pertanian dan Peternakan Provinsi Sulawesi Utara memiliki kriteria efektivitas yang bervariasi dari tahun 2012 sampai dengan tahun 2016. Pada tahun 2012 tingkat efektivitas dari angaran belanja Dinas Pertanian dan Peternakan Provinsi Sulawesi Utara berada dalam kriteria yang cukup efektif. Walau masuk dalam kriteria yang cukup efektif, realisasi anggaran yang dicapai masih cukup jauh perbedannya untuk memenuhi target anggaran yang ditetapkan. Dan pada tahun 2013 sampai tahun 2016 tingkat efektivitas sudah masuk dalam kriteria efektif, tetapi masih seperti tahun sebelumnya realisasi anggaran yang dicapai masih cukup berbeda dengan target anggaran. Naik turunnya tingkat efektivitas anggaran belanja disebabkan karena realisasi anggaran yang dicapai tidak sesuai dengan target yang ditetapkan. Walaupun ada program yang terealisasi tapi tidak sesuai dengan anggaran yang ditetapkan ada juga beberapa kegiatan yang dianggarkan tidak terealisasi, tetapi kegiatan lain yang telah dianggarkan sudah dilaksanakan dengan efektif oleh Dinas Pertanian dan Peternakan Provinsi Sulawesi Utara.

2. Tingkat atau kriteria efisiensi Dinas Pertanian dan Peternakan Provinsi Sulawesi Utara tahun 2012 -2016, secara keseluruan sudah di olah dengan baik, dimana pada tahun 2012 tingkat efisiensi 40,19\%, tahun 2013 tingkat efisiensi 56,53\%, dan tahun 2014 tingkat efisiensi 45,51\%, tahun 2015 tingkat efisiensi 40,78\% dan tahun 2016 tingkat efisiensi 57,70\% . jadi anggaran belanja pada Dinas Pertanian dan Peternakan Provinsi Sulawesi Utara sudah memiliki kriteria yang sangat efisien, karena tingkat efisiensi 
semua berada dibawah 60\%. Pengelolaan anggaran belanja ini sudah berhasil memenuhi syarat efisiensi yaitu penggunaan dana yang minimum untuk mencapai hasil yg maksimal.

\subsection{Saran}

Dalam rangka menghadapi otonomi daerah khususnya mempersiapkan sumber daya manusia, Untuk instansi tempat dilakukannya penelitian yaitu Dinas Pertanian dan Peternakan Provinsi Sulawesi Utara agar lebih meningkatkan tingkat efektifitas pada tahun yang akan datang dengan melakukan perencanaan untuk memenuhi target anggaran yang akan ditetapkan guna tercapainya kriteria yang sangat efektif dan sebaiknya anggaran yang ditargetkan untuk suatu program dapat dilaksanakan agar tingkat efektivitasnya bisa mencapai target. Dan tingkat efisien untuk Dinas Pertanian dan Peternakan Provinsi Sulawesi Utara agar tetap mempertahankan tingkat efisiennya yang dimana disetiap tahun mengalami perubahan yang sangat baik dimana tingkat efisien tiap tahunnya masuk dalam kriteria yang sangat efisisen.

\section{DAFTAR PUSTAKA}

Agustina, Oesi. 2013. Analisis Kinerja Keuangan Daerah dan Tingkat Kemandirian Daerah di Era Otonomi Daerah: Study Kasus KotaMalang (Tahun Anggaran 2007-2011). http:/jimfeb.ub.ac.id.

Endah, V.S. Cicilia. 2015. Analisis Efesiensi dan Efektivitas Serta Kemandirian Pengelolaan Keuangan Daerah Di Kabupaten Minahasa Utara. Jurnal Pembangunan Ekonomi Dan Keuangan Daerah, Vol. 17, No. 2.

Klychova G.S 2014. Budgeting Efficiency for Cost Control Purposein Management Accounting System. Kazan State University Rusia.

Mandey, R.M. Kevin. 2015.Analisis Kinerja Pendapatan Asli Daerah Dikaitkan Dengan Belanja Daerah Pada Pemerintah Kota Bitung. Jurnal EMBA.

Mardiasmo. 2009. Akuntansi Sektor Publik. Andi. Yogyakarta

Mathews, Joseph R. 2011.”Assesing Organizational Effectiveness: The Role Of Performance Measures”. Library Quarterly Vol. 81 No. 1, The University of Chicago.

Pontoh, Winston. 2013. Akuntansi: Konsep dan Aplikasi. Halaman Moeka, Jakarta Barat.

Sumenge, Aril. 2013. Analisis Efektivitas dan Efisiensi Pelaksanaan Anggaran Belanja Badan Perencanaan Pembangunan Daerah (BAPPEDA) Minahasa Selatan. Jurnal Akuntansi dan Manajemen. Vol. 1 No.3 ISSN 2303-1174 Hal. 74-81, September 2013

Sujarweni, V. Wirtna. 2015. Akuntansi Sektor Publik. Pustaka Baru Press. Yogyakarta. 